\title{
Fingolimod Associated Bilateral Cystoid Macular Edema-Wait and See?
}

\author{
Refik Pul 1,*,+, Alma Osmanovic ${ }^{1,+}$, Holger Schmalstieg ${ }^{2}$, Amelie Pielen ${ }^{3}$, Kaweh Pars ${ }^{1}$, \\ Philipp Schwenkenbecher ${ }^{1}$, Kurt Wolfram Sühs ${ }^{1}$, Özlem Yildiz ${ }^{1}$, Benedikt Frank ${ }^{4}$, \\ Martin Stangel ${ }^{1}$ and Thomas Skripuletz ${ }^{1}$ \\ 1 Department of Neurology, Hannover Medical School, 30625 Hannover, Germany; \\ osmanovic.alma@mh-hannover.de (A.O.); pars.kaweh@mh-hannover.de (K.P.); \\ Schwenkenbecher.Philipp@MH-Hannover.de (P.S.); suehs.kurt-wolfram@mh-hannover.de (K.W.S.); \\ yildiz.oezlem@mh-hannover.de (Ö.Y.); Stangel.Martin@mh-hannover.de (M.S.); \\ skripuletz.thomas@mh-hannover.de (T.S.) \\ 2 Private Ophthalmology Office, 30851 Langenhagen, Germany; info@dr-holger-schmalstieg.de \\ 3 Department of Ophthalmology, Hannover Medical School, 30625 Hannover, Germany; \\ pielen.amelie@mh-hannover.de \\ 4 Department of Neurology, University of Duisburg-Essen, 45147 Essen, Germany; \\ benedikt.frank@uk-essen.de \\ * Correspondence: pul.refik@MH-Hannover.de; Tel.: +49-511-532-3118; Fax: +49-511-532-3119 \\ + These authors contributed equally to this work.
}

Academic Editor: Sven Meuth

Received: 29 July 2016; Accepted: 7 December 2016; Published: 14 December 2016

\begin{abstract}
Fingolimod 0.5-mg once-daily is an approved therapy for patients with relapsing-remitting multiple sclerosis (MS). Several pivotal and real-world studies have demonstrated that fingolimod is associated with the development of macular edema (ME). Herein, we present a case of a diabetic MS patient who developed severe bilateral ME during fingolimod treatment. By means of this case study we provide a detailed review about fingolimod associated macular edema (FAME), its current incidence with or without diabetes mellitus, and previous therapy attempts and outcomes in MS patients. Intravitreal administration of antibodies raised against vascular endothelial growth factor $\mathrm{A}$ (VEGF-A) has not yet been used in the management of FAME, however, the excellent therapeutic response in our patient may justify the use of anti-VEGF-A agents in combination with cessation of fingolimod to achieve fast resolution of FAME and to prevent visual deficits, particularly in bilateral FAME.
\end{abstract}

Keywords: multiple sclerosis; fingolimod; macular edema; VEGF; diabetes mellitus

\section{Introduction}

Fingolimod was approved in the European Union in March 2011 as 0.5-mg once-daily therapy for patients with highly active relapsing-remitting multiple sclerosis (RRMS) [1]. It prevents the B and $\mathrm{T}$ lymphocyte egress from lymphoid tissues by inducing aberrant internalization of the sphingosine 1-phosphate (S1P) receptor and, thereby, reduces recirculation of autoaggressive lymphocytes to the central nervous system [2].

Originally, fingolimod was evaluated as a treatment for renal transplant rejection, wherein patients received higher doses of fingolimod ( 2.5 and $5 \mathrm{mg}$ ), in combination with cyclosporine, tacrolimus, and/or steroids [3-6]. In this context, macular edema (ME) has been identified as a specific adverse event of fingolimod in renal transplant patients [3-6]. In the phase II core study of fingolimod in multiple sclerosis (MS) and its extensions, two high doses of fingolimod (1.25 and $5.0 \mathrm{mg}$ ) were administered and none of the patients developed ME [7-10]. However, besides several organ-specific 
adverse events, ME was observed in patients receiving fingolimod during four phase III MS trials (FREEDOMS, FREEDOMSII, TRANSFORMS, and INFORMS) [11-13]. Since the licensing, we have treated 74 MS patients with fingolimod and one of these patients with type 1 diabetes mellitus (DM) developed bilateral diffuse cystoid ME. The aim of this study was to report the successful use of ranibizumab, an antibody raised against human vascular endothelial growth factor A (VEGF-A), in fingolimod-associated macular edema (FAME) and to provide a detailed review about this adverse event with emphasis on diabetic MS patients.

\section{Case Presentation}

A then 28-year-old Caucasian woman presented with right-sided hemihypesthesia and weakness of the right leg in March 2013. Magnetic resonance imaging showed multiple contrast-enhancing cranial and spinal lesions indicating high disease activity. Diagnosis of RRMS was made based on the revised McDonald criteria 2010 [14] supported by cerebrospinal fluid results and exclusionary laboratory tests. Prior to diagnosis, she suffered from weakness of her right leg for several weeks in 2010 and 2012. Moreover, in December 2012, she had blurred vision in the right eye for a few weeks. The only concomitant diseases were type I DM since the age of 18 , treated with both long- and rapid-acting insulin (insulin glargine and aspart), and arterial hypertension, treated with enalapril $2.5 \mathrm{mg}$ once daily. The patient was obese with a weight of $80 \mathrm{~kg}$, height of $153 \mathrm{~cm}$, and a BMI of $34.2 \mathrm{~kg} / \mathrm{m}^{2}$. HBA1c values (December 2012: 9.4\%, April 2013: 9.1\%, July 2013: 9.8\%, December 2013: 10.1\%), cholesterol (December 2012: 212 mg/dL, April 2013: 301 mg/dL, July 2013: 299 mg/dL, December 2013: $210 \mathrm{mg} / \mathrm{dL}$ ), as well as triglyceride levels (December 2012: $261 \mathrm{mg} / \mathrm{dL}$, April 2013: 373 mg/dL, July 2013: 446 mg/dL, December 2013: 318 mg/dL) were markedly increased.

Intravenous steroid treatments ( $1 \mathrm{~g}$ methylprednisolone daily over five days) in March and April 2013 were considered insufficiently effective because of persisting paresis of the right leg. In May 2013, plasmapheresis was initiated and led to a slow but complete resolution of the paresis resulting in an expanded disability status scale score of 2.0 due to mild coordination deficits, reflex inequalities, absent cutaneous reflexes, and urinary urgency.

Because of the high disease activity, fingolimod was started at the end of July 2013. An ophthalmic examination before initiating fingolimod therapy was not performed. Four weeks later she complained about a progressive decrease in vision in her left eye. Best corrected visual acuity was 20/20 in her right and 20/25 in her left eye. Funduscopic examinations revealed a mild non-proliferative diabetic retinopathy in both eyes (see Figure 1A,B). Spectral domain optical coherence tomography (OCT) showed cystoid ME in the left eye with a central foveal thickness of $264 \mu \mathrm{m}$ in the right and $463 \mu \mathrm{m}$ in the left eye (Figure 2; 27 August 2013). Fingolimod was discontinued immediately. Two weeks later, ME was detected in both eyes, the central foveal thickness on OCT increased to $642 \mu \mathrm{m}$ in the right and to $709 \mu \mathrm{m}$ in the left eye and, after another week, slightly decreased to $618 \mu \mathrm{m}$ and $648 \mu \mathrm{m}$ in the right and left eye, respectively (Figure 2; 9 and 16 September 2013). Fluorescein angiography documented diffuse cystoid ME in both eyes, affecting the left eye more significantly (Figure 1G,H). Since the patient's visual acuity rapidly deteriorated to $20 / 160$ in both eyes, a volume of $0.05 \mathrm{~mL}$ ranibizumab $(0.5 \mathrm{mg}$; Lucentis ${ }^{\circledR}$ ) was injected into each vitreous cavity of both eyes on 16 September 2013 using a 30-gauge needle after topical anesthesia. Already after one week following administration of ranibizumab, a rapid and sustained remission of the bilateral ME was attained (Figure 2; 24 September 2013). Despite this improvement, intravitreal injection of ranibizumab into both eyes was repeated on 16 October 2013 because of bilateral central and nasal scotoma as assessed by Amsler grid testing. Best corrected visual acuity increased to 20/63 in both eyes, while treatment did not lead to any change of the scotoma. In a follow-up examination on 16 August 2015, best corrected visual acuity was 20/20 in both eyes, scotoma had significantly regressed and OCT examination did not reveal any ME (foveal thickness of 196 und $197 \mu \mathrm{m}$ in the right and left eye, respectively). 


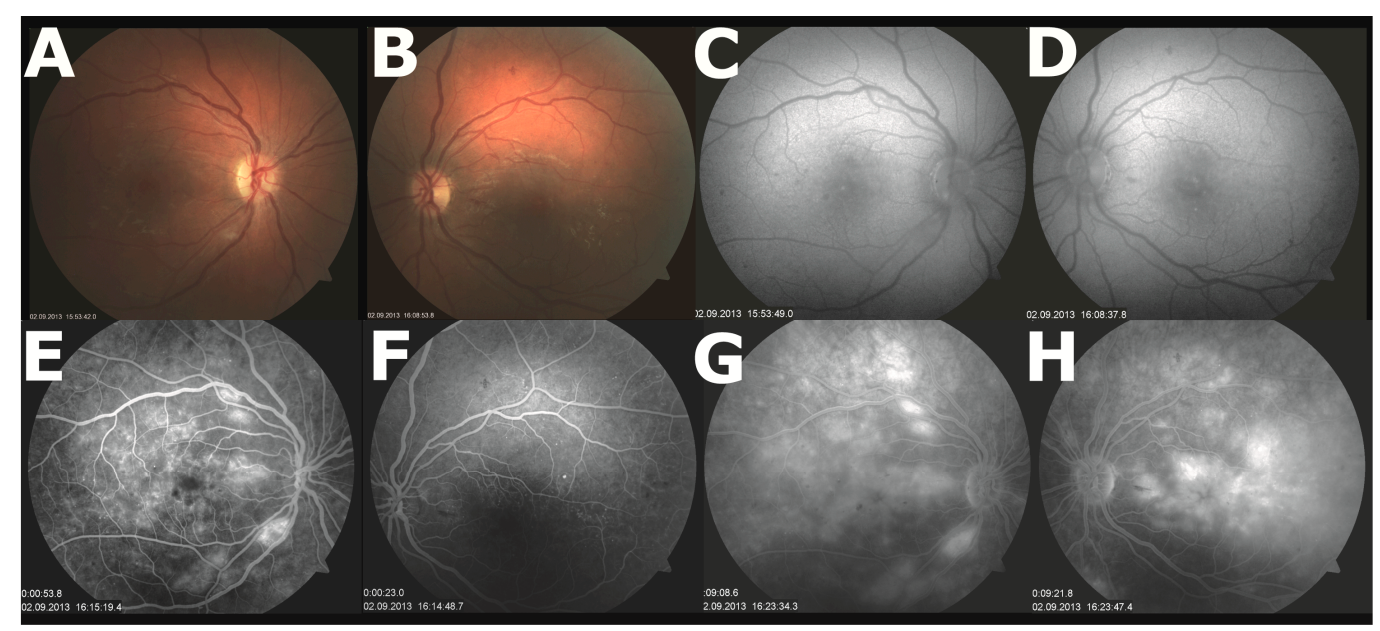

Figure 1. Results of the fundus photography and fluorescein angiography examinations. (A,B) Fundus photography of the right eye (A) revealed one small cotton-wool spot over the right inferior arcade and few intraretinal dot-and-blot hemorrhages temporal to the fovea centralis, but no hard exudates. In the left eye (B), it displayed few dot-and-blot hemorrhages in the superior and temporal area. Findings were in agreement with mild non-proliferative diabetic retinopathy; (C,D) Red free fundus photography allowed better visualization of the dot-and-blot hemorrhages in the right (C) and left (D) eye; (E,F) Early-phase fluorescein angiography of the right eye (E) showed diffuse macular hyperfluorescence and few microaneurysms. In the left eye (F), few microaneurysms were visible and it was not possible to assess the perifoveal arcade; $(\mathbf{G}, \mathbf{H})$ Late-phase fluorescein angiography reveals diffuse cystoid macular edema the right $(\mathbf{G})$ and more pronounced in the left eye $(\mathbf{H})$.

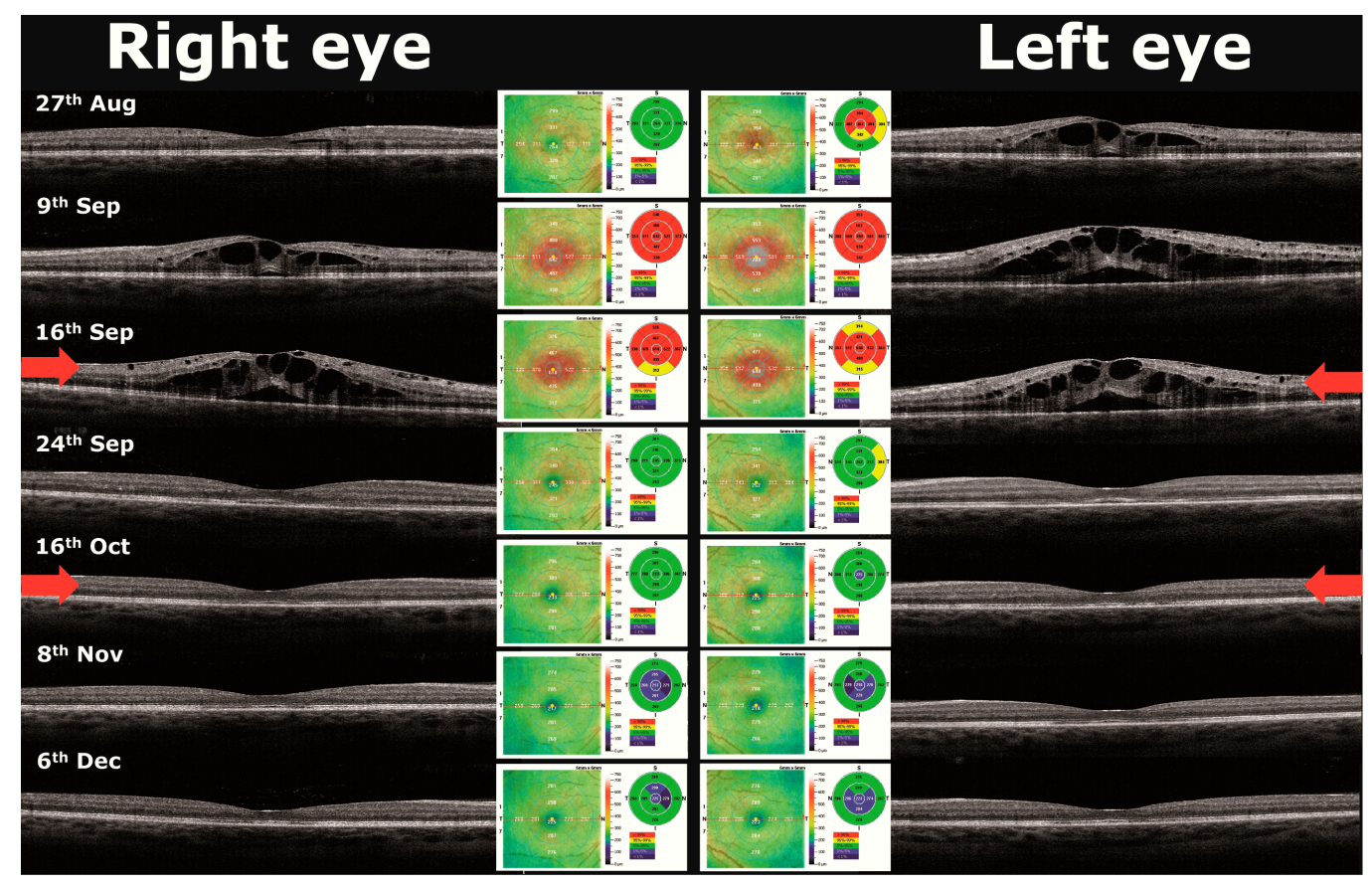

Figure 2. Results of the spectral-domain optical coherence tomography examinations. Spectral-domain optical coherence tomography scans through the fovea show development of severe macular edema with intraretinal und subretinal fluid and its rapid resolution after intravitreal injection of an anti-vascular endothelial growth factor (VEGF) agent into each vitreous cavity of both eyes on 16 September 2013. On 24 September 2013 optical coherence tomography (OCT) shows residual alterations of the outer retina on both eyes. Red arrows mark the intravitreal injection. 


\section{Discussion}

ME refers to accumulation of fluid in the outer plexiform and inner nuclear layers around the fovea and represents a sequel to a variety of pathologic conditions. Though it accompanies many different diseases, the disruption of the blood-retinal barrier (BRB) in perifoveal capillaries and breakdown of mechanisms that prevent the accumulation of extracellular fluid in the retina are considered to be the common cause for ME [15]. Several systemically and locally administered drugs have been implicated in the development of ME (reviewed in [15]). A possible association between fingolimod and ME has been put forward in one randomized, phase III study of renal transplant rejection even though the percentage of patients who developed ME was higher in the comparator group [5]. Three phase II/III studies have revealed that, in fact, it occurred more frequently in the fingolimod than in the comparator group $[3,4,6]$, while no ME has been reported in two phase II studies in renal transplant patients (Table 1) [16,17]. However, there is almost no difference in the incidence of ME between the fingolimod (1.9\%) and placebo/comparator group (2.0\%) when dividing the number of ME cases from all renal transplant rejection studies by the total population enrolled (Table 1). However, the period of one dose-finding study [16] was rather short and regular eye examinations were performed only in one study [4]. It was speculated that the higher incidence of ME might be a result of having enrolled more subjects with risk factors (retinal vascular diseases, past ocular surgery, uveitis, DM, diabetic retinopathy) in the fingolimod group [6]. None of the renal transplantation study reports (Table 1) clarify how many patients with ME had DM. Several authors who cited these studies have claimed that patients with DM are at increased risk of developing ME when using fingolimod, although there is yet no evidence for this association [18-22]. This apprehensiveness probably became evident after the start of the fingolimod phase II MS study [7] because in all subsequent studies ([23], Table 2) DM was an exclusion criterion (Table 2). In phase III MS studies and their extensions, exclusion of DM as a confounding factor unveiled that, indeed, there is a dose-dependent association and ME has been reported to occur typically within three to four months after commencing fingolimod (Table 2). Overall, the incidence of ME is $0.2 \%$ when the proportion of the treatment is subtracted from that of the placebo/comparator group $(0.8 \%$ minus $0.6 \%$; Table 2$)[7,12]$. The selective incidence in the treatment group, on the other hand, is in line with those of one retrospective and one open-label "real-world" observation $(0.9 \%, 3 / 317$ [18]; 0.8\%, 19/2417 [24]). However, in other studies with smaller numbers of patients no ME was observed [25-27] (Table 3).

Table 1. Frequency of macular edema in clinical trials that evaluated efficacy of fingolimod in renal transplant rejection. * This study was a dose-finding study, wherein, in addition to $0.5 \mathrm{mg}$ fingolimod, doses of $0.25(n=43), 0.5(n=43)$, and $1.0 \mathrm{mg}(n=40)$ of fingolimod were also administered to study participants. No macular edema was observed at any of these dosages.

\begin{tabular}{|c|c|c|c|c|c|c|}
\hline Study & Phase & $\begin{array}{l}\text { Fingolimod } \\
2.5 \mathrm{mg} \%(n)\end{array}$ & $\begin{array}{l}\text { Fingolimod } \\
5 \mathrm{mg} \%(n)\end{array}$ & $\begin{array}{c}\text { Placebo or Active } \\
\text { Comparator }\end{array}$ & Combination & $\begin{array}{c}\text { Exposition } \\
\text { Time }\end{array}$ \\
\hline $\begin{array}{l}\text { Tedesco-Silva et al. } \\
2004[16]^{*}\end{array}$ & II & $0 \%(0 / 41)$ & - & $0 \%(0 / 41)$ & $\begin{array}{l}\text { Cyclosporine } \\
+ \text { Steroids }\end{array}$ & 3 months \\
\hline $\begin{array}{l}\text { Tedesco-Silva et al. } \\
\text { 2006 [3] }\end{array}$ & III & $1.8 \%(4 / 224)$ & $3.4 \%(8 / 234)$ & $1.3 \%(3 / 229)$ & $\begin{array}{l}\text { Cyclosporine } \\
+ \text { Steroids }\end{array}$ & 12 months \\
\hline $\begin{array}{l}\text { Salvadori et al. } \\
2006[5]\end{array}$ & III & $1.3 \%(3 / 219)$ & $2.2 \%(5 / 224)$ & $3 \%(6 / 226)$ & $\begin{array}{l}\text { Cyclosporine } \\
+ \text { Steroids }\end{array}$ & 12 months \\
\hline $\begin{array}{l}\text { Mulgaonkar et al. } \\
2006 \text { [17] }\end{array}$ & II & $0 \%(0 / 150)$ & $0 \%(0 / 72)$ & $0 \%(0 / 39)$ & $\begin{array}{l}\text { Cyclosporine } \\
+ \text { Steroids }\end{array}$ & 12 months \\
\hline $\begin{array}{l}\text { Tedesco-Silva et al. } \\
2007 \text { [4] }\end{array}$ & II & $1.1 \%(1 / 89)$ & $0 \%(0 / 87)$ & $0 \%(0 / 94)$ & $\begin{array}{l}\text { Cyclosporine } \\
+ \text { Steroids }\end{array}$ & 12 months \\
\hline $\begin{array}{l}\text { Hoitsma et al. } \\
2011 \text { [6] }\end{array}$ & III & $12.2 \%(6 / 48)$ & - & $9.3 \%(5 / 54)$ & $\begin{array}{l}\text { Tacrolimus }+ \\
\text { Steroids }\end{array}$ & 12 months \\
\hline \multirow{2}{*}{ Summary } & & $1.8 \%(14 / 771)$ & $2.1 \%(13 / 617)$ & $2.0 \%(14 / 683)$ & - & - \\
\hline & & \multicolumn{2}{|c|}{$1.9 \%(27 / 1388)$} & - & - & - \\
\hline
\end{tabular}


Table 2. Frequency of macular edema in multiple sclerosis clinical trials. Percentage incidence was calculated by dividing the number of macula edema cases in the study by the total population enrolled in the reviewed studies. * One case of macular edema has been reported in the continuous fingolimod group but without specifying the fingolimod dosage. n.a. = not applicable.

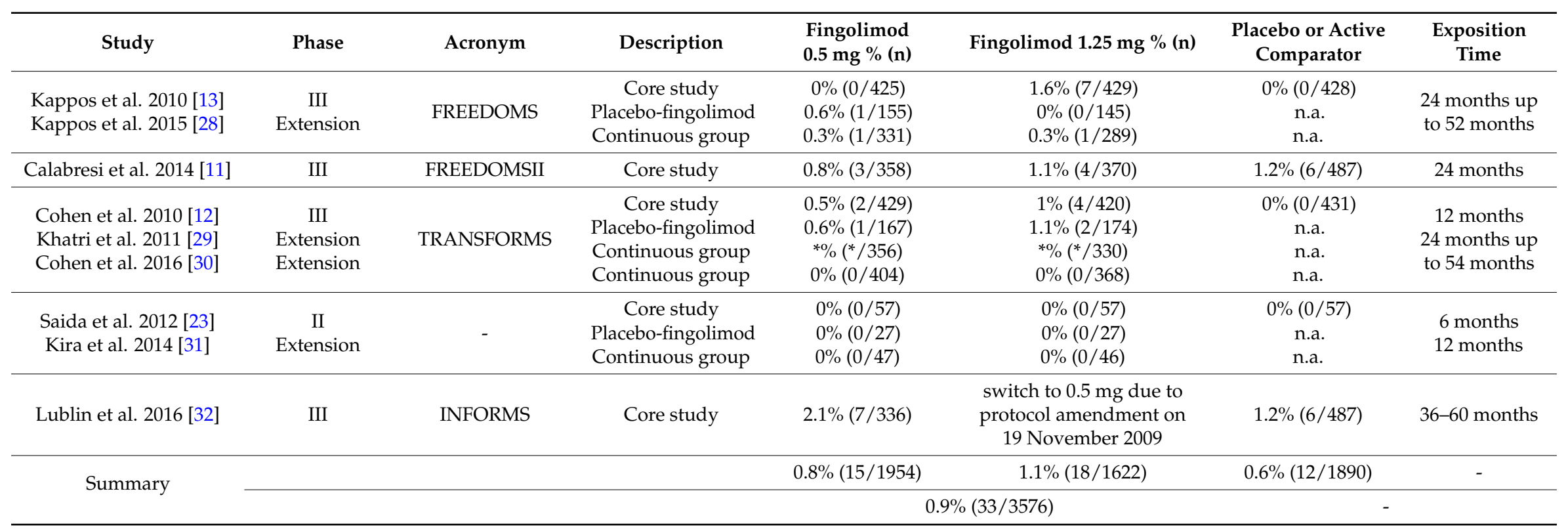


Table 3. Frequency of macular edema (ME) cases in real-world multiple sclerosis (MS) populations. n.m. = not mentioned; n.a. = not applicable.

\begin{tabular}{ccccccc}
\hline Study & $n$ & Study Type & $\begin{array}{c}\text { Study Duration/ } \\
\text { Follow-up Time }\end{array}$ & $\begin{array}{c}\text { ME Cases } \\
(\boldsymbol{n})\end{array}$ & $\begin{array}{c}n \text { Diabetic } \\
\text { MS Patients }\end{array}$ & $\begin{array}{c}n \text { ME in Diabetic } \\
\text { MS Patients }\end{array}$ \\
\hline $\begin{array}{c}\text { Ontenada et al. } \\
\text { 2012 [18] }\end{array}$ & 317 & Retrospective & 3 months & 3 & 12 & 1 \\
\hline Gold et al. 2014 [24] & 2417 & Open-label & 4 months & 19 & 26 & 1 \\
\hline $\begin{array}{c}\text { Al-Hashel et al. } \\
\text { 2014 [27] }\end{array}$ & 175 & Retrospective & Up to 22 months & 0 & n.m. & n.a. \\
\hline $\begin{array}{c}\text { Ordoncmrẽz-Boschetti } \\
\text { et al. 2015 [26] }\end{array}$ & 138 & Open-label & 4 months & 0 & n.m. & n.a. \\
\hline Correia et al. 2016 [25] & 104 & Retrospective & Up to 21 months & 0 & n.m. & n.a. \\
\hline
\end{tabular}

Diabetic ME (DME) is one manifestation of diabetic retinopathy and a meta-analysis of 35 population-based studies worldwide suggests a considerable prevalence of $7 \%$ in the diabetic population [33]. According to this meta-analysis the prevalence of DME is more than twice as high in subjects with type $1(14 \%)$ than in those with type 2 diabetes $(6 \%)$ [33]. Several modifiable and unmodifiable risk factors, like cholesterol level [33,34], poor glycemic control [33,35], systolic blood pressure [35], presence of diabetic nephropathy [35], diabetes duration [35], higher age at onset [34], and retinal microaneurysm count [36], have been shown to influence susceptibility to the formation of ME in type 1 diabetes. Of these risk factors, we can confirm that our patient had a poor glycemic and cholesterol/triglyceride control, increased systolic blood pressure values, and a higher age at onset of type 1 diabetes (cumulative incidence of $34 \%$ at onset group 15-40 years [34]).

In our patient, OCT scans of both macular regions did not reveal any microaneurysm that could be attributed as a potential leakage source, suggesting a generalized breakdown of the BRB. The diffuse cystoid occurrence accompanied by neurosensory retinal detachment is common in DME, but uncommon in eyes with mild, non-proliferative diabetic retinopathy [37]. The immediate onset of bilateral ME after commencing treatment with fingolimod points to an association with this treatment. DME constitutes a chronic disease subject to recurrences and, in general, requires longer treatment with ranibizumab $[38,39]$. Complete and long-term restoration of macular thickness and/or visual acuity after only two injections of ranibizumab is fairly unlikely for DME and this therefore represents the main argument that our patient experienced FAME. FAME has been reported by more than a dozen case studies (Table 4) and it should be stressed that the typical pattern of macular edema evident in the fluorescein angiogram typically displays focal (perifoveal) retinal capillary dye leakage [40-45].

So far, only two cases of ME in diabetic MS subjects following fingolimod treatment have been reported in case studies (Table 4). The mean time of occurrence seems to be shorter in these patients $(0.5 \pm 0.4$ months; $n=3$ including our case) as compared to non-diabetic MS patients ( $2.8 \pm 0.5$ months), but the number of diabetic cases is too low to perform statistical analysis. All diabetic MS patients developed bilateral ME speculating that retinal alterations due to diabetic retinopathy may be the cause for this symmetric occurrence. Apart from these single case reports, and in contrast to the clinical development studies, MS patients with controlled DM were included in real-world observations (Table 3). Of these observations, only two studies present the numbers of diabetic MS patients and of those who have suffered from ME [18,24]. Based on the total number of diabetic MS patients from these studies there is an incidence of $5.3 \%$, which is approximately seven times higher than in non-diabetic patients. However, none of these studies stated the presence and/or degree of retinopathy, duration and type of DM, and whether ME occurred on a bi- or unilateral basis. The incidence data of ME in diabetic patients without MS vary from $0 \%$ (3 years follow-up) up to $26.1 \%$ (25 years follow-up) [40], suggesting an actually higher incidence in fingolimod-treated diabetic MS subjects. 
Table 4. Case studies of fingolimod associated macular edema in multiple sclerosis (MS) patients * except one subject who was a renal transplant recipient in a phase IIIb clinical trial of fingolimod. $\mathrm{M}=$ male; $\mathrm{F}=$ female; $\mathrm{U}=$ unilateral; $\mathrm{B}=$ bilateral; $\mathrm{ST}=$ subtenon; $\mathrm{IV}=$ intravitreal; $\mathrm{R}=$ resolved; $\mathrm{NR}=$ not resolved; $\mathrm{NM}=$ not mentioned.

\begin{tabular}{|c|c|c|c|c|c|c|c|c|}
\hline Study & Age & Gender & Diabetes/Uveitis & $\begin{array}{c}\text { Onset } \\
\text { (Months) }\end{array}$ & $\begin{array}{l}\text { Time of Resolution } \\
\text { (Months) }\end{array}$ & $\begin{array}{c}\text { Uni- or } \\
\text { Bilateral }\end{array}$ & Fingolimod & Therapy (Outcome) \\
\hline Saab et al. $2008 *[46]$ & 58 & F & No & 3.0 & 2.0 & $\mathrm{U}$ & Discontinued & - \\
\hline $\begin{array}{l}\text { Turaka and Bryan } \\
2012[47]\end{array}$ & 52 & M & No & 3.0 & 3.0 & $\mathrm{U}$ & Discontinued & Prednisolone \\
\hline $\begin{array}{l}\text { Liu and Cuthbertson } \\
2012[48]\end{array}$ & 34 & F & No & 0.2 & NR. & B & Discontinued & $\begin{array}{c}\text { Ketorolac and prednisolone (persistence of minimal ME } \\
\text { in the right eye after } 5 \text { months) }\end{array}$ \\
\hline \multirow{3}{*}{ Afshar et al. 2013 [49] } & 52 & M & No & 0.2 & 1.0 & $\mathrm{U}$ & Continued & Nepafenac and prednisolone \\
\hline & 60 & $\mathrm{~F}$ & Diabetes & 0.3 & 1.0 & B & Discontinued & - \\
\hline & 57 & M & No & 1.0 & NR & $\mathrm{U}$ & Discontinued & $\begin{array}{c}\text { Bromfenac (epiretinal membrane and still increased foveal } \\
\text { thickness after } 3 \text { months) }\end{array}$ \\
\hline Chui et al. 2013 [50] & 67 & F & No & 6.0 & 1.2 & $\mathrm{U}$ & Discontinued & Ketorolac and dexamethasone \\
\hline Minuk et al. 2013 [51] & 58 & F & Uveitis & 2.0 & 1.0 & B & Discontinued & Ketorolac, prednisolone, ST triamcinolone injection \\
\hline Coppes et al. 2013 [21] & 60 & F & Diabetes & 0.3 & 1.6 & B & Discontinued & - \\
\hline Li et al. 2014 [22] & 37 & F & No & 4.0 & NR & $\mathrm{U}$ & Continued & $\begin{array}{c}- \\
\text { (not resolved after } 25 \text { months) }\end{array}$ \\
\hline Kim et al. 2015 [52] & 62 & F & No & 2.5 & 1.0 & B & Discontinued & Ketorolac and prednisolone \\
\hline Ueda and Saida 2015 [53] & 31 & M & No & 1.0 & 1.0 & $\mathrm{U}$ & Discontinued & $\begin{array}{c}\text { Betamethasone (resolved in } 1 \text { month but persistence of } \\
\text { decreased visual acuity) }\end{array}$ \\
\hline Schröder et al. 2015 [54] & 24 & $\mathrm{~F}$ & No & 1.0 & NM & B & Discontinued & $\begin{array}{l}\text { Acetazolamide (visual acuity returned to normal after } 2 \\
\text { weeks while it remains unknown whether ME resolved) }\end{array}$ \\
\hline \multirow{2}{*}{ Thoo et al. 2015 [55] } & 59 & $\mathrm{~F}$ & No & 0.7 & 1.0 & $\mathrm{~B}$ & Continued & Prednisolone and IV triamcinolone \\
\hline & 66 & $\mathrm{~F}$ & No & 12.0 & 2.0 & $\mathrm{U}$ & Continued & $\begin{array}{l}\text { Keterolac and prednisolone IV triamcinolone } \\
\text { (resolved in } 1 \text { week after IV triamcinolone) }\end{array}$ \\
\hline
\end{tabular}


The efficacy of fingolimod is mainly reliant on its phosphate ester metabolite, which acts as a high-affinity ligand for the G-protein-coupled receptors $\mathrm{S}_{1} \mathrm{P}_{1}$ and $\mathrm{S}_{1} \mathrm{P}_{3-5}$ with the highest affinity for the $\mathrm{S}_{1} \mathrm{P}_{1}$ receptor [41,42]. For the $\mathrm{S}_{1} \mathrm{P}_{1}$ receptor, it has been shown that fingolimod phosphate initially operates as a functional agonist and overstimulates it, which causes endocytic internalization and the uncoupling of the receptor from its $G$ protein receptor by the recruitment of $\beta$-arrestins to the receptor complex [41]. In the long run, fingolimod acts as a functional antagonist because its sustained exposure causes a reduction in the $\mathrm{S}_{1} \mathrm{P}_{1}$ receptor numbers on the cell surface $[42,43]$. In vitro studies have shown that this reduction persists even after discontinuation of treatment, suggesting a disturbed recycling of the receptor back to the plasma membrane, for example, by repeated dissociation-association cycles of fingolimod phosphate [41,44]. The $\mathrm{S}_{1} \mathrm{P}_{1}$ receptor, which is highly expressed on endothelial cells, has been implicated in the regulation of the vascular endothelial barrier function by cell cytoskeleton rearrangement and assembly of intercellular junctions [45,56,57]. Several in vitro and rodent studies have clearly demonstrated that fingolimod promotes tightening of the endothelial cell barrier [58-61]. All these studies, however, have in common that fingolimod was not administered continuously [58-60] or given over a short period [61], suggesting that their results most probably reflect the initial stimulation of the $\mathrm{S}_{1} \mathrm{P}_{1}$ receptor. Owing to the fact that continuous treatment with fingolimod decreases surface expression of the $\mathrm{S}_{1} \mathrm{P}_{1}$ receptor and that $\mathrm{S}_{1} \mathrm{P}_{2} / \mathrm{S}_{1} \mathrm{P}_{3}$ activation increases endothelial barrier permeability [62], one possible explanation for the development of ME might be a shift of the balance from $\mathrm{S}_{1} \mathrm{P}_{1}$ towards $\mathrm{S}_{2} \mathrm{P}_{2} / \mathrm{S}_{1} \mathrm{P}_{3}$ signaling resulting in the activation of Rho/ROCK signaling pathways [62]. However, in one recent study, attenuation of retinal vascular leakages after a 12-week fingolimod treatment in streptozotocin (STZ)-induced diabetic rats has been reported [63]. Moreover, there are several works underlining that long-term treatment with fingolimod does not impair endothelial barrier function [64,65], which might be explained by the fact that, despite membrane downregulation, the internalized $\mathrm{S}_{1} \mathrm{P}_{1}$ receptor still actuates signaling pathways [66] or that this function does not depend on the $\mathrm{S}_{1} \mathrm{P}_{1}$ receptor at all [67]. Conversely, it has been shown that long-term treatment with fingolimod worsens vascular leakage in bleomycin-induced lung injury [68]. Thus, it remains completely unclear how fingolimod might trigger ME.

VEGF-A, known to increase microvascular permeability, is one of the major contributors to the development of ME and is markedly elevated in patients with diabetic retinopathy [69]. In the literature, there are different results regarding the expression of VEGF-A under fingolimod therapy. Decreased VEGF-A expression/secretion has been reported in cholangiocarcinoma [70] and decidual natural killer cells [71], in lung injury [72], and renal fibrosis model [64]. Fingolimod did not alter VEGF-A expression in chondrocytes [73]. Following fingolimod treatment, increased VEGF-A expression/secretion has been observed in the periinfarct cortex after photothrombotic stroke [74] and in Jurkat cells [75]. These disparate results may reflect concentration-depending effects or be based upon different signaling pathways depending on the target tissue/cell. To our knowledge, there is currently no study that examined direct effects of fingolimod on endothelial VEGF-A secretion.

Intraocular injection of VEGF-neutralizing antibodies is a first-line treatment for DME, but it has hitherto not been used in the management of FAME. Anti-inflammatory topical medications, such as prostaglandin synthesis inhibitors (nepafenac, bromfenac, ketorelac), carbonic anhydrase inhibitor (acetazolamide), and steroids (prednisolone, dexamethasone, difluprednate), have been reported to improve resolution of ME (Table 4). For the efficacy of those topical medications, discontinuation of fingolimod seems to be a critical step, as otherwise ME may remain unresolved [22], prolong its resolution [54], recur [50], or be associated with other eye complications [51,54]. In more severe ME cases, some patients experienced only partial $[22,49,51]$ or no recovery [55] by topical medications. Notably, some of these patients were treated successfully with intravitreous [55] or subtenon injection of a synthetic steroid (triamcinolone) [51] as a second-line therapy. Similar to our case, the intravitreal injection particularly resulted in hastened resolution of ME [55] as compared to a mere discontinuation of fingolimod or treatment with topical drugs. Such a rapid resolution is exactly required in bilateral ME because the "wait-and-see" strategy may lead to longer periods of incapacity for work and might 
result in residual visual deficits. We preferred the anti-VEGF therapy in order to avoid steroid-related adverse events, such as ocular hypertension, glaucoma, and cataract formation. The intraocular injection of this agent was well tolerated by our patient and ME resolved already after one injection. A second injection was given due to the presence of scotoma which, interestingly, did not respond to this treatment as quickly as the ME did, but regressed considerably within a few weeks. However, our patient still exhibits small scotomas in the central field of both eyes and we think that earlier treatment may have prevented them.

In conclusion, for the approved fingolimod dose, the current incidence of FAME is $0.2 \%$. Real-world observations point to a higher incidence of FAME in diabetic MS subjects, but their numbers are too low to provide accurate incidence data. FAME in diabetic MS patients seems to occur earlier and is more frequently associated with bilateral occurrence. Bilateral occurrence of ME is an extensively debilitating condition that warrants early and effective treatment. Discontinuation of fingolimod in combination with intraocular injection of anti-VEGF-A agents may provide fast resolution of ME and prevent visual deficits. More data about diabetic MS patients treated with fingolimod are required to estimate accurate incidence data, identify factors that militate against fingolimod treatment, and to establish a treatment guideline for the management of ME. Future research is required to elucidate whether fingolimod modulates the expression of endothelial VEGF-A and whether increased VEGF-A serum levels predispose for the development of ME. Hitherto existing data indicate that diabetes mellitus is a relative contraindication for fingolimod treatment. Anti-VEGF drugs need to be evaluated in nondiabetic patients in order to gain certainty of their general efficacy in FAME.

Author Contributions: Refik Pul, Amelie Pielen, Martin Stangel, Thomas Skripuletz, Kurt Wolfram Sühs and Kaweh Pars wrote the manuscript. Alma Osmanovic, Holger Schmalstieg, Özlem Yildiz, Philipp Schwenkenbecher, and Benedikt Frank prepared figures and tables.

Conflicts of Interest: The authors declare no conflict of interest.

\section{References}

1. European Medicines Agency. Annex I. Summary of Product Characteristics. Gilenya (fingolimod). 2011. (last updated 07.03.2016). Available online: http://www.ema.europa.eu/docs/en_GB/document_library/ EPAR_-_Product_Information/human/002202/WC500104528.pdf (accessed on 20 July 2016).

2. Brinkmann, V.; Davis, M.D.; Heise, C.E.; Albert, R.; Cottens, S.; Hof, R.; Bruns, C.; Prieschl, E.; Baumruker, T.; Hiestand, P.; et al. The immune modulator FTY720 targets sphingosine 1-phosphate receptors. J. Biol. Chem. 2002, 277, 21453-21457. [CrossRef] [PubMed]

3. Tedesco-Silva, H.; Pescovitz, M.D.; Cibrik, D.; Rees, M.A.; Mulgaonkar, S.; Kahan, B.D.; Gugliuzza, K.K.; Rajagopalan, P.R.; Esmeraldo Rde, M.; Lord, H.; et al. Randomized controlled trial of FTY720 versus MMF in de novo renal transplantation. Transplantation 2006, 82, 1689-1697. [CrossRef] [PubMed]

4. Tedesco-Silva, H.; Szakaly, P.; Shoker, A.; Sommerer, C.; Yoshimura, N.; Schena, F.P.; Cremer, M.; Hmissi, A.; Mayer, H.; Lang, P. FTY720 versus mycophenolate mofetil in de novo renal transplantation: Six-month results of a double-blind study. Transplantation 2007, 84, 885-892. [CrossRef] [PubMed]

5. Salvadori, M.; Budde, K.; Charpentier, B.; Klempnauer, J.; Nashan, B.; Pallardo, L.M.; Eris, J.; Schena, F.P.; Eisenberger, U.; Rostaing, L.; et al. FTY720 versus MMF with cyclosporine in de novo renal transplantation: A 1-year, randomized controlled trial in Europe and Australasia. Am. J. Transplant. 2006, 6, 2912-2921. [CrossRef] [PubMed]

6. Hoitsma, A.J.; Woodle, E.S.; Abramowicz, D.; Proot, P.; Vanrenterghem, Y. FTY720 combined with tacrolimus in de novo renal transplantation: 1-year, multicenter, open-label randomized study. Nephrol. Dial. Transplant. 2011, 26, 3802-3805. [CrossRef] [PubMed]

7. Kappos, L.; Antel, J.; Comi, G.; Montalban, X.; O'Connor, P.; Polman, C.H.; Haas, T.; Korn, A.A.; Karlsson, G.; Radue, E.W. Oral fingolimod (FTY720) for relapsing multiple sclerosis. N. Engl. J. Med. 2006, 355, 1124-1140. [CrossRef] [PubMed] 
8. O'Connor, P.; Comi, G.; Montalban, X.; Antel, J.; Radue, E.W.; de Vera, A.; Pohlmann, H.; Kappos, L. Oral fingolimod (FTY720) in multiple sclerosis: Two-year results of a phase II extension study. Neurology 2009, 72 , 73-79. [CrossRef] [PubMed]

9. Comi, G.; O'Connor, P.; Montalban, X.; Antel, J.; Radue, E.W.; Karlsson, G.; Pohlmann, H.; Aradhye, S.; Kappos, L. Phase II study of oral fingolimod (FTY720) in multiple sclerosis: 3-year results. Mult. Scler. 2010, 16, 197-207. [CrossRef] [PubMed]

10. Izquierdo, G.; O'Connor, P.; Montalban, X.; von Rosenstiel, P.; Cremer, M.; de Vera, A.; Sfikas, N.; Francis, G.; Radue, E.; Kappos, L. Five-year results from a phase 2 study of oral fingolimod in relapsing multiple sclerosis. Mult. Scler. 2013, 20, 877-881. [CrossRef] [PubMed]

11. Calabresi, P.A.; Radue, E.W.; Goodin, D.; Jeffery, D.; Rammohan, K.W.; Reder, A.T.; Vollmer, T.; Agius, M.A.; Kappos, L.; Stites, T.; et al. Safety and efficacy of fingolimod in patients with relapsing-remitting multiple sclerosis (FREEDOMS II): A double-blind, randomised, placebo-controlled, phase 3 trial. Lancet Neurol. 2014, 13, 545-556. [CrossRef]

12. Cohen, J.A.; Barkhof, F.; Comi, G.; Hartung, H.P.; Khatri, B.O.; Montalban, X.; Pelletier, J.; Capra, R.; Gallo, P.; Izquierdo, G.; et al. Oral fingolimod or intramuscular interferon for relapsing multiple sclerosis. N. Engl. J. Med. 2010, 362, 402-415. [CrossRef] [PubMed]

13. Kappos, L.; Radue, E.W.; O'Connor, P.; Polman, C.; Hohlfeld, R.; Calabresi, P.; Selmaj, K.; Agoropoulou, C.; Leyk, M.; Zhang-Auberson, L.; et al. A placebo-controlled trial of oral fingolimod in relapsing multiple sclerosis. N. Engl. J. Med. 2010, 362, 387-401. [CrossRef] [PubMed]

14. Polman, C.H.; Reingold, S.C.; Banwell, B.; Clanet, M.; Cohen, J.A.; Filippi, M.; Fujihara, K.; Havrdova, E.; Hutchinson, M.; Kappos, L.; et al. Diagnostic criteria for multiple sclerosis: 2010 revisions to the McDonald criteria. Ann. Neurol. 2011, 69, 292-302. [CrossRef] [PubMed]

15. Makri, O.E.; Georgalas, I.; Georgakopoulos, C.D. Drug-induced macular edema. Drugs 2013, 73, 789-802. [CrossRef] [PubMed]

16. Tedesco-Silva, H.; Mourad, G.; Kahan, B.D.; Boira, J.G.; Weimar, W.; Mulgaonkar, S.; Nashan, B.; Madsen, S.; Charpentier, B.; Pellet, P.; et al. FTY720, a novel immunomodulator: Efficacy and safety results from the first phase 2A study in de novo renal transplantation. Transplantation 2004, 77, 1826-1833. [CrossRef] [PubMed]

17. Mulgaonkar, S.; Tedesco, H.; Oppenheimer, F.; Walker, R.; Kunzendorf, U.; Russ, G.; Knoflach, A.; Patel, Y.; Ferguson, R. FTY720/cyclosporine regimens in de novo renal transplantation: A 1-year dose-finding study. Am. J. Transplant. 2006, 6, 1848-1857. [CrossRef] [PubMed]

18. Ontaneda, D.; Hara-Cleaver, C.; Rudick, R.A.; Cohen, J.A.; Bermel, R.A. Early tolerability and safety of fingolimod in clinical practice. J. Neurol. Sci. 2012, 323, 167-172. [CrossRef] [PubMed]

19. Zarbin, M.A.; Jampol, L.M.; Jager, R.D.; Reder, A.T.; Francis, G.; Collins, W.; Tang, D.; Zhang, X. Ophthalmic evaluations in clinical studies of fingolimod (FTY720) in multiple sclerosis. Ophthalmology 2013, 120, 1432-1439. [CrossRef] [PubMed]

20. Jain, N.; Bhatti, M.T. Fingolimod-associated macular edema: Incidence, detection, and management. Neurology 2012, 78, 672-680. [CrossRef] [PubMed]

21. Coppes, O.J.; Gutierrez, I.; Reder, A.T.; Ksiazek, S.; Bernard, J. Severe early bilateral macular edema following fingolimod therapy. Mult. Scler. Relat. Disord. 2013, 2, 256-258. [CrossRef] [PubMed]

22. Li, V.; Kane, J.; Chan, H.H.; Hall, A.J.; Butzkueven, H. Continuing fingolimod after development of macular edema: A case report. Neurol. Neuroimmunol. Neuroinflamm. 2014, 1, e13. [CrossRef] [PubMed]

23. Saida, T.; Kikuchi, S.; Itoyama, Y.; Hao, Q.; Kurosawa, T.; Nagato, K.; Tang, D.; Zhang-Auberson, L.; Kira, J. A randomized, controlled trial of fingolimod (FTY720) in Japanese patients with multiple sclerosis. Mult. Scler. 2012, 18, 1269-1277. [CrossRef] [PubMed]

24. Gold, R.; Comi, G.; Palace, J.; Siever, A.; Gottschalk, R.; Bijarnia, M.; von Rosenstiel, P.; Tomic, D.; Kappos, L. Assessment of cardiac safety during fingolimod treatment initiation in a real-world relapsing multiple sclerosis population: A phase 3b, open-label study. J. Neurol. 2014, 261, 267-276. [CrossRef] [PubMed]

25. Correia, I.; Batista, S.; Marques, I.B.; Sousa, M.; Ferreira, R.; Nunes, C.; Macario, M.C.; Sousa, L. The effectiveness of fingolimod in a Portuguese real-world population. Mult. Scler. Relat. Disord. 2016, 6, 41-48. [CrossRef] [PubMed]

26. Ordonez-Boschetti, L.; Rey, R.; Cruz, A.; Sinha, A.; Reynolds, T.; Frider, N.; Alvarenga, R. Safety and Tolerability of Fingolimod in Latin American Patients with Relapsing-Remitting Multiple Sclerosis: The Open-Label FIRST LATAM Study. Adv. Ther. 2015, 32, 626-635. [CrossRef] [PubMed] 
27. Al-Hashel, J.; Ahmed, S.F.; Behbehani, R.; Alroughani, R. Real-world use of fingolimod in patients with relapsing remitting multiple sclerosis: A retrospective study using the national multiple sclerosis registry in Kuwait. CNS Drugs 2014, 28, 817-824. [CrossRef] [PubMed]

28. Kappos, L.; O'Connor, P.; Radue, E.W.; Polman, C.; Hohlfeld, R.; Selmaj, K.; Ritter, S.; Schlosshauer, R.; von Rosenstiel, P.; Zhang-Auberson, L.; et al. Long-term effects of fingolimod in multiple sclerosis: The randomized FREEDOMS extension trial. Neurology 2015, 84, 1582-1591. [CrossRef] [PubMed]

29. Khatri, B.; Barkhof, F.; Comi, G.; Hartung, H.P.; Kappos, L.; Montalban, X.; Pelletier, J.; Stites, T.; Wu, S.; Holdbrook, F.; et al. Comparison of fingolimod with interferon $\beta-1 \alpha$ in relapsing-remitting multiple sclerosis: A randomised extension of the TRANSFORMS study. Lancet Neurol. 2011, 10, 520-529. [CrossRef]

30. Cohen, J.A.; Khatri, B.; Barkhof, F.; Comi, G.; Hartung, H.P.; Montalban, X.; Pelletier, J.; Stites, T.; Ritter, S.; von Rosenstiel, P.; et al. Long-term (up to 4.5 years) treatment with fingolimod in multiple sclerosis: Results from the extension of the randomised TRANSFORMS study. J. Neurol. Neurosurg. Psychiatry 2016, 87, 468-475. [CrossRef] [PubMed]

31. Kira, J.; Itoyama, Y.; Kikuchi, S.; Hao, Q.; Kurosawa, T.; Nagato, K.; Tsumiyama, I.; von Rosenstiel, P.; Zhang-Auberson, L.; Saida, T. Fingolimod (FTY720) therapy in Japanese patients with relapsing multiple sclerosis over 12 months: Results of a phase 2 observational extension. BMC Neurol. 2014, 14, 21. [CrossRef] [PubMed]

32. Lublin, F.; Miller, D.H.; Freedman, M.S.; Cree, B.A.; Wolinsky, J.S.; Weiner, H.; Lubetzki, C.; Hartung, H.P.; Montalban, X.; Uitdehaag, B.M.; et al. Oral fingolimod in primary progressive multiple sclerosis (INFORMS): A phase 3, randomised, double-blind, placebo-controlled trial. Lancet 2016, 387, 1075-1084. [CrossRef]

33. Yau, J.W.; Rogers, S.L.; Kawasaki, R.; Lamoureux, E.L.; Kowalski, J.W.; Bek, T.; Chen, S.J.; Dekker, J.M.; Fletcher, A.; Grauslund, J.; et al. Global prevalence and major risk factors of diabetic retinopathy. Diabetes Care 2012, 35, 556-564. [CrossRef] [PubMed]

34. Hietala, K.; Forsblom, C.; Summanen, P.; Groop, P.H. Higher age at onset of type 1 diabetes increases risk of macular oedema. Acta Ophthalmol. 2013, 91, 709-715. [CrossRef] [PubMed]

35. Klein, R.; Knudtson, M.D.; Lee, K.E.; Gangnon, R.; Klein, B.E. The Wisconsin Epidemiologic Study of Diabetic Retinopathy XXIII: The twenty-five-year incidence of macular edema in persons with type 1 diabetes. Ophthalmology 2009, 116, 497-503. [CrossRef] [PubMed]

36. Rasmussen, M.L.; Broe, R.; Frydkjaer-Olsen, U.; Olsen, B.S.; Mortensen, H.B.; Peto, T.; Grauslund, J. Microaneurysm count as a predictor of long-term progression in diabetic retinopathy in young patients with type 1 diabetes: The Danish Cohort of Pediatric Diabetes 1987 (DCPD1987). Graefes Arch. Clin. Exp. Ophthalmol. 2015, 253, 199-205. [CrossRef] [PubMed]

37. Kang, S.W.; Park, C.Y.; Ham, D.I. The correlation between fluorescein angiographic and optical coherence tomographic features in clinically significant diabetic macular edema. Am. J. Ophthalmol. 2004, 137, 313-322. [CrossRef] [PubMed]

38. Mitchell, P.; Bandello, F.; Schmidt-Erfurth, U.; Lang, G.E.; Massin, P.; Schlingemann, R.O.; Sutter, F.; Simader, C.; Burian, G.; Gerstner, O.; et al. The RESTORE study: Ranibizumab monotherapy or combined with laser versus laser monotherapy for diabetic macular edema. Ophthalmology 2011, 118, 615-625. [CrossRef] [PubMed]

39. Massin, P.; Bandello, F.; Garweg, J.G.; Hansen, L.L.; Harding, S.P.; Larsen, M.; Mitchell, P.; Sharp, D.; Wolf-Schnurrbusch, U.E.; Gekkieva, M.; et al. Safety and efficacy of ranibizumab in diabetic macular edema (RESOLVE Study): A 12-month, randomized, controlled, double-masked, multicenter phase II study. Diabetes Care 2010, 33, 2399-2405. [CrossRef] [PubMed]

40. Lee, R.; Wong, T.Y.; Sabanayagam, C. Epidemiology of diabetic retinopathy, diabetic macular edema and related vision loss. Eye Vis. 2015, 2, 17. [CrossRef] [PubMed]

41. Sykes, D.A.; Riddy, D.M.; Stamp, C.; Bradley, M.E.; McGuiness, N.; Sattikar, A.; Guerini, D.; Rodrigues, I.; Glaenzel, A.; Dowling, M.R.; et al. Investigating the molecular mechanisms through which FTY720-P causes persistent $\mathrm{S1P}_{1}$ receptor internalization. Br. J. Pharmacol. 2014, 171, 4797-4807. [CrossRef] [PubMed]

42. Camm, J.; Hla, T.; Bakshi, R.; Brinkmann, V. Cardiac and vascular effects of fingolimod: Mechanistic basis and clinical implications. Am. Heart J. 2014, 168, 632-644. [CrossRef] [PubMed]

43. Oo, M.L.; Thangada, S.; Wu, M.T.; Liu, C.H.; Macdonald, T.L.; Lynch, K.R.; Lin, C.Y.; Hla, T. Immunosuppressive and anti-angiogenic sphingosine 1-phosphate receptor-1 agonists induce ubiquitinylation and proteasomal degradation of the receptor. J. Biol. Chem. 2007, 282, 9082-9089. [CrossRef] [PubMed] 
44. Graler, M.H.; Goetzl, E.J. The immunosuppressant FTY720 down-regulates sphingosine 1-phosphate G-protein-coupled receptors. FASEB J. 2004, 18, 551-553. [CrossRef] [PubMed]

45. McVerry, B.J.; Peng, X.; Hassoun, P.M.; Sammani, S.; Simon, B.A.; Garcia, J.G. Sphingosine 1-phosphate reduces vascular leak in murine and canine models of acute lung injury. Am. J. Respir. Crit. Care Med. 2004, 170, 987-993. [CrossRef] [PubMed]

46. Saab, G.; Almony, A.; Blinder, K.J.; Schuessler, R.; Brennan, D.C. Reversible cystoid macular edema secondary to fingolimod in a renal transplant recipient. Arch. Ophthalmol. 2008, 126, 140-141. [CrossRef] [PubMed]

47. Turaka, K.; Bryan, J.S. Does fingolimod in multiple sclerosis patients cause macular edema? J. Neurol. 2012, 259, 386-388. [CrossRef] [PubMed]

48. Liu, L.; Cuthbertson, F. Early bilateral cystoid macular oedema secondary to fingolimod in multiple sclerosis. Case Rep. Med. 2012, 2012, 134636. [CrossRef] [PubMed]

49. Afshar, A.R.; Fernandes, J.K.; Patel, R.D.; Ksiazek, S.M.; Sheth, V.S.; Reder, A.T.; Hariprasad, S.M. Cystoid macular edema associated with fingolimod use for multiple sclerosis. JAMA Ophthalmol. 2013, 131, 103-107. [CrossRef] [PubMed]

50. Chui, J.; Herkes, G.K.; Chang, A. Management of fingolimod-associated macular edema. JAMA Ophthalmol. 2013, 131, 694-696. [CrossRef] [PubMed]

51. Minuk, A.; Belliveau, M.J.; Almeida, D.R.; Dorrepaal, S.J.; Gale, J.S. Fingolimod-associated macular edema: Resolution by sub-tenon injection of triamcinolone with continued fingolimod use. JAMA Ophthalmol. 2013, 131, 802-804. [CrossRef] [PubMed]

52. Kim, M.J.; Bhatti, M.T.; Costello, F. Famous. Surv. Ophthalmol. 2016, 61, 512-519. [CrossRef] [PubMed]

53. Ueda, N.; Saida, K. Retinal hemorrhages following fingolimod treatment for multiple sclerosis; a case report. BMC Ophthalmol. 2015, 15, 135. [CrossRef] [PubMed]

54. Schroder, K.; Finis, D.; Harmel, J.; Ringelstein, M.; Hartung, H.P.; Geerling, G.; Aktas, O.; Guthoff, R. Acetazolamide therapy in a case of fingolimod-associated macular edema: Early benefits and long-term limitations. Mult. Scler. Relat. Disord. 2015, 4, 406-408. [CrossRef] [PubMed]

55. Thoo, S.; Cugati, S.; Lee, A.; Chen, C. Successful treatment of fingolimod-associated macular edema with intravitreal triamcinolone with continued fingolimod use. Mult. Scler. 2015, 21, 249-251. [CrossRef] [PubMed]

56. Tauseef, M.; Kini, V.; Knezevic, N.; Brannan, M.; Ramchandaran, R.; Fyrst, H.; Saba, J.; Vogel, S.M.; Malik, A.B.; Mehta, D. Activation of sphingosine kinase-1 reverses the increase in lung vascular permeability through sphingosine-1-phosphate receptor signaling in endothelial cells. Circ. Res. 2008, 103, 1164-1172. [CrossRef] [PubMed]

57. Lee, M.J.; Thangada, S.; Claffey, K.P.; Ancellin, N.; Liu, C.H.; Kluk, M.; Volpi, M.; Sha'afi, R.I.; Hla, T. Vascular endothelial cell adherens junction assembly and morphogenesis induced by sphingosine-1-phosphate. Cell 1999, 99, 301-312. [CrossRef]

58. Nishihara, H.; Shimizu, F.; Sano, Y.; Takeshita, Y.; Maeda, T.; Abe, M.; Koga, M.; Kanda, T. Fingolimod prevents blood-brain barrier disruption induced by the sera from patients with multiple sclerosis. PLoS ONE 2015, 10, e0121488. [CrossRef] [PubMed]

59. Peng, X.; Hassoun, P.M.; Sammani, S.; McVerry, B.J.; Burne, M.J.; Rabb, H.; Pearse, D.; Tuder, R.M.; Garcia, J.G. Protective effects of sphingosine 1-phosphate in murine endotoxin-induced inflammatory lung injury. Am. J. Respir. Crit. Care Med. 2004, 169, 1245-1251. [CrossRef] [PubMed]

60. Wang, L.; Chiang, E.T.; Simmons, J.T.; Garcia, J.G.; Dudek, S.M. FTY720-induced human pulmonary endothelial barrier enhancement is mediated by c-Abl. Eur. Respir. J. 2011, 38, 78-88. [CrossRef] [PubMed]

61. Foster, C.A.; Mechtcheriakova, D.; Storch, M.K.; Balatoni, B.; Howard, L.M.; Bornancin, F.; Wlachos, A.; Sobanov, J.; Kinnunen, A.; Baumruker, T. FTY720 rescue therapy in the dark agouti rat model of experimental autoimmune encephalomyelitis: Expression of central nervous system genes and reversal of blood-brain-barrier damage. Brain Pathol. 2009, 19, 254-266. [CrossRef] [PubMed]

62. Lee, J.F.; Gordon, S.; Estrada, R.; Wang, L.; Siow, D.L.; Wattenberg, B.W.; Lominadze, D.; Lee, M.J. Balance of $\mathrm{S}_{1} \mathrm{P}_{1}$ and $\mathrm{S}_{1} \mathrm{P}_{2}$ signaling regulates peripheral microvascular permeability in rat cremaster muscle vasculature. Am. J. Physiol. Heart Circ. Physiol. 2009, 296, H33-H42. [CrossRef] [PubMed]

63. Fan, L.; Yan, H. FTY720 Attenuates Retinal Inflammation and Protects Blood-Retinal Barrier in Diabetic Rats. Investig. Ophthalmol. Vis. Sci. 2016, 57, 1254-1263. [CrossRef] [PubMed] 
64. Ni, H.; Chen, J.; Pan, M.; Zhang, M.; Zhang, J.; Chen, P.; Liu, B. FTY720 prevents progression of renal fibrosis by inhibiting renal microvasculature endothelial dysfunction in a rat model of chronic kidney disease. J. Mol. Histol. 2013, 44, 693-703. [CrossRef] [PubMed]

65. Yin, Z.; Fan, L.; Wei, L.; Gao, H.; Zhang, R.; Tao, L.; Cao, F.; Wang, H. FTY720 protects cardiac microvessels of diabetes: A critical role of S1P1/3 in diabetic heart disease. PLoS ONE 2012, 7, e42900. [CrossRef] [PubMed]

66. Mullershausen, F.; Zecri, F.; Cetin, C.; Billich, A.; Guerini, D.; Seuwen, K. Persistent signaling induced by FTY720-phosphate is mediated by internalized S1P 1 receptors. Nat. Chem. Biol. 2009, 5, 428-434. [CrossRef] [PubMed]

67. Dudek, S.M.; Camp, S.M.; Chiang, E.T.; Singleton, P.A.; Usatyuk, P.V.; Zhao, Y.; Natarajan, V.; Garcia, J.G. Pulmonary endothelial cell barrier enhancement by FTY720 does not require the $\mathrm{S}_{1} \mathrm{P}_{1}$ receptor. Cell Signal. 2007, 19, 1754-1764. [CrossRef] [PubMed]

68. Shea, B.S.; Brooks, S.F.; Fontaine, B.A.; Chun, J.; Luster, A.D.; Tager, A.M. Prolonged exposure to sphingosine 1-phosphate receptor-1 agonists exacerbates vascular leak, fibrosis, and mortality after lung injury. Am. J. Respir. Cell Mol. Biol. 2010, 43, 662-673. [CrossRef] [PubMed]

69. Zhang, X.; Bao, S.; Hambly, B.D.; Gillies, M.C. Vascular endothelial growth factor-A: A multifunctional molecular player in diabetic retinopathy. Int. J. Biochem. Cell Biol. 2009, 41, 2368-2371. [CrossRef] [PubMed]

70. Lu, Z.; Wang, J.; Zheng, T.; Liang, Y.; Yin, D.; Song, R.; Pei, T.; Pan, S.; Jiang, H.; Liu, L. FTY720 inhibits proliferation and epithelial-mesenchymal transition in cholangiocarcinoma by inactivating STAT3 signaling. BMC Cancer 2014, 14, 783. [CrossRef] [PubMed]

71. Zhang, J.; Dunk, C.E.; Lye, S.J. Sphingosine signalling regulates decidual NK cell angiogenic phenotype and trophoblast migration. Hum. Reprod. 2013, 28, 3026-3037. [CrossRef] [PubMed]

72. Qian, J.; Ye, Y.; Lv, L.; Zhu, C.; Ye, S. FTY720 attenuates paraquat-induced lung injury in mice. Int. Immunopharmacol. 2014, 21, 426-431. [CrossRef] [PubMed]

73. Masuko, K.; Murata, M.; Beppu, M.; Nakamura, H.; Kato, T.; Yudoh, K. Sphingosine-1-phosphate modulates expression of vascular endothelial growth factor in human articular chondrocytes: A possible new role in arthritis. Int. J. Rheum. Dis. 2012, 15, 366-373. [CrossRef] [PubMed]

74. Brunkhorst, R.; Kanaan, N.; Koch, A.; Ferreiros, N.; Mirceska, A.; Zeiner, P.; Mittelbronn, M.; Derouiche, A.; Steinmetz, H.; Foerch, C.; et al. FTY720 treatment in the convalescence period improves functional recovery and reduces reactive astrogliosis in photothrombotic stroke. PLoS ONE 2013, 8, e70124. [CrossRef] [PubMed]

75. Wang, F.; Tan, W.; Guo, D.; Zhu, X.; Qian, K.; He, S. Altered expression of signaling genes in Jurkat cells upon FTY720 induced apoptosis. Int. J. Mol. Sci. 2010, 11, 3087-3105. [CrossRef] [PubMed] 